\title{
Development of Quadrilateral and Triangle Learning Devices in Lower Secondary with the Scientific Approach Oriented to Problem Solving Ability
}

\author{
Inggrid Marlissa ${ }^{1}$, Nurhayati ${ }^{2}$ \\ Mathematics Education Department \\ Universitas Musamus \\ Merauke, Indonesia \\ 1'inggrid_fkip@unmus.ac.id, ${ }^{2}$ nurhayati_fkip@unmus.ac.id
}

\begin{abstract}
This research aimed to produce Lower Secondary Mathematics Teaching Materials with the Scientific Approach Oriented to Problem Solving Ability including Lesson Plan (RPP), Student Working Sheet (LKS), and a valid, practical and effective student Learning Achievement Test (TPB). This type of research was a research and development method. The development model referred to was to use a 4-D development model consisting of four stages: define, design, develop, and disseminate. The research instruments used were validation sheets, teacher practicality sheets, student practicality sheets, learning implementation observation sheets, and Learning Achievement Tests. The results showed that the development products are included in very valid categories according to experts, very practical according to the teacher's assessment, and practical according to students and the results of learning achievement tests meet the effective category.
\end{abstract}

Keywords-Teaching materials; scientific approach; problem solving abilities

\section{INTRODUCTION}

Mathematics is used in various fields of knowledge including science, social knowledge, medical science, and commerce. This illustrates that mathematics is a science that is beneficial to life so that mathematics is important to learn. However, mathematical objects that are abstract and loaded with symbols and mathematical terms often complicate students in learning mathematics. There are students who are able to understand the material well but are unable to apply the material to more complex problems. This is in line with the results of TIMSS 2015, the math score of 397 placing Indonesia at the bottom of the rank which is the $45^{\text {th }}$ out of 50 countries. In general, Indonesian students are weak in all content and cognitive aspects, both for mathematics and science [1].

According to Gagne [2], there are indirect objects that can be obtained by students in learning mathematics, such as the ability to solve problems, the ability to think, to be independent, and to be respectful of mathematics. So, mathematics not merely teaches knowledge of mathematics, but also the mindset and devices in everyday life. In the attachment of Regulation of Minister of National Education no. 22 of 2006 concerning Content Standards states that the purpose of mathematics learning is that students have the ability to: 1) understand mathematical concepts; 2) use reasoning on patterns and traits; 3) solve problems; 4) communicate; 5) have an attitude of respecting the usefulness of mathematics in life.

Ref [3] explained that "a problem-solving disposition includes the confidence and willingness to take on new and difficult tasks". Solving problems requires the ability to see useful information and use the knowledge they possess as well as possible. The knowledge of problem solving strategies provides many choices in determining the steps that will be used to solve a problem.

Pimta, Tayruakham, \& Nuangchalerm [4] stated that "mathematical problem is the device used as not only to help students develop their thinking ability but it also helps them to develop their basic skills of solving the problems especially a problem in daily life". In line with this, Kennedy, Tipps, \& Johnson [5] stated that mathematics has various practical benefits in everyday life.

According to Santrock [6] there are four steps that must be passed by individuals to solve problems, which are:

a. searching and limiting the problems,

b. developing a good problem solving solution,

c. evaluating the solution, and

d. thinking and redefining problems and solutions from time to time

In line with this, Bransford and Stein [7] developed problem-solving steps with memorable title, named: IDEAL, "I (Identify the Problem), D (Define and represent the problem), E (Explore possible strategies), A (Act on the strategies), and L (Look back and evaluate the effects of your activities)".

From the description above, it can be concluded that the problem solving ability is the high order thinking ability of students to solve new or difficult problems and is an integral part of every process of learning mathematics and very useful in everyday life. It can be said that the problem in mathematics is a task that must be done by students by using 
analysis and completion steps and using procedures to achieve the expected results.

There are three components of the problem solving process: resources, strategies, and cognitive control which are described as follows [8]:

\section{1) resources}

The reference for knowing students' resources is to determine the degree of knowledge and observe facts, concepts and procedures used by students in solving problems.

2) strategies

Souviney classified the strategies used by students in the process of solving mathematical problems as follows:
a) guessing and testing;
b) substituting simpler values;
c) dividing problem into subtasks;
d) conducting an investigation;
e) designing a model;
f) drawing a sketch;
g) making a systematic list;
h) making a table;
i) constructing a graph;
j) reducing to a simpler case;
k) searching for a pattern;
l) constructing a general rule (function);
m) working backward; and
n) adding something to the problem situation.
3) cognitive control

Cognitive control is how students make decisions about what will be done on a good problem in the form of planning, and decision making, which in this case is assessed based on the reflexive-impulsive cognitive style in the category of fast responding/high-error, fast responding/low-error, slowresponding/low-error, or slow-responding/high-error.

Problem solving is part of the mathematics curriculum which is very important because in the learning process and its completion, students are allowed to gain experience using their knowledge and to be applied to problem solving. But this is considered the most difficult part in learning it and for the teacher in working on it. This is in line with research conducted by [9] explaining that $15.87 \%$ of students have moderate problem-solving abilities and $30.16 \%$ of students have low problem-solving abilities.

One of the things that can be done so that the ability to solve mathematical problems is better is the need to design a learning that makes students actively involved in the learning process. Learning design is related to learning planning, because learning planning is the steps prepared by the teacher before carrying out a learning activity. Planning can be interpreted as the process of preparing learning objectives, subject matter, use of learning media, use of learning approaches, learning methods, allocation of learning time and learning assessment. All that has been mentioned can be found on the learning device, namely the syllabus, lesson plan (RPP), teaching materials, and student worksheets (LKS).

National Center for Vocational Education Research Ltd/National Center for Competency Based Training in the book of the Development of Teaching Materials[10], explained that teaching materials are all forms of materials used to assist teachers/instructors in carrying out teaching and learning activities in the classroom. The material in question can be in the form of written or unwritten material.

The teaching materials used by the teacher have been less interesting and varied. For example, most textbooks are found to contain material, sample questions, practice questions, and so on. Lesson plan owned by the teacher also does not contain activities that utilize something tangible such as objects or events around students. The lack of teaching materials that utilize concrete things around students causes students' understanding of a material to be difficult. Students have difficulty in developing their understanding because the things they meet in teaching materials tend to be abstract and unfamiliar. Mathematical concepts and ideas must be studied as an activity in the classroom that is implemented in learning through solving problems that are familiar with students' daily lives. Therefore, the teaching materials given to students emphasize more on something "real" so that it can help students in understanding mathematical concepts. The "real" thing here is something that exists and is often encountered by students in their environment. Many things in the surrounding environment can be used as learning resources for students.

The approach used in the preparation of this teaching material is a scientific approach. This relates to the 2013 curriculum that has been applied at every level of education. The outcome expected from this curriculum is the improvement and balance between the ability to be a good human being (soft skills) and to have the skills and knowledge for proper living (hard skills) which includes aspects of attitude, skills and knowledge competencies [11].

The 5M activity in the Scientific Approach involves observing, questioning, gathering information/trying, associating/reasoning, and communicating [12]. Correspondingly, [13] stated that the scientific approach includes five learning experiences: observing, questioning, gathering information/experimenting, reasoning/associating, and communicating.

\section{RESEARCH METHODS}

This type of research was a research and development method. The development model used was the 4D development model. The development model consists of four stages: define, design, develop, and disseminate (Thiagarajan, Semmel \& Semmel in [14]).

This research was carried out in Merauke 2 Public Lower Secondary School and Merauke 8 Public Lower Secondary School from April to June 2018. The population used in this research was the seventh grade students. The limited trial was 
carried out in Merauke 2 Public Lower Secondary school while the Field Trial was held in Merauke 8 Public Lower Secondary school.

Trials are carried out to improve the teaching material developed by practicing it directly in the field. The trials carried out are as follows:

\section{a) Expert and Practitioner Test}

This expert and practitioner test is to validate the product before being tested in the field. Expert and practitioner tests were carried out by mathematical learning experts and experienced mathematics teachers to assess and provide criticism and suggestions on the initial products of developed instructional materials.

\section{b) Limited Trial}

Limited trials in the form of legibility tests were carried out by giving an assessment sheet in the form of suggestions and comments to students on the developed teaching materials. Some students were asked to provide suggestions and comments on the students working sheets (LKS) that will be tested in the field. The results of this trial were used as a basis for improving LKS so that it can be used in field trials.

\section{c) Field Trial}

At this stage the learning process and observation of the trial class were performed. Mathematics teachers carried out classroom learning and researchers as observers to observe classroom learning activities.

The instruments used in this research were validation sheets, practicality assessment sheets by the teacher, practicality assessment sheets by the student, learning implementation observation sheets, and learning achievement tests.

Data obtained through device validation sheets, teacher assessment sheets, student assessment sheets, learning approach implementation sheets, and learning outcome tests were analyzed using descriptive statistics. Data in the form of rating with a scale of 5 were converted into qualitative data which was also on a scale of 5 . Data conversion criteria was conducted based on the criteria presented in Table 1 below. To assess the feasibility of the developed learning device, the validity, effectiveness, and practicality were reviewed.

TABLE I. CONVERSION CRITERIA OF QUANTITATIVE DATA FOR QUALITATIVE DATA

\begin{tabular}{|l|c|c|}
\hline No & Interval Score & Category \\
\hline 1 & $\bar{x}>M_{i}+1,5 S B_{i}$ & Very Valid \\
\hline 2 & $M_{i}+0,5 S B_{i}<\bar{x} \leq M_{i}+1,5 S B_{i}$ & Good \\
\hline 3 & $M_{i}-0,5 S B_{i}<\bar{x} \leq M_{i}+0,5 S B_{i}$ & Average \\
\hline 4 & $M_{i}-1,5 S B_{i}<\bar{x} \leq M_{i}-0,5 S B_{i}$ & Fair \\
\hline 5 & $\bar{x} \leq M_{i}-1,5 S B_{i}$ & Poor \\
\hline
\end{tabular}

Remark:

$M_{i}=$ Ideal Mean

$M_{i}=\frac{1}{2}($ Score Max Ideal + Score Min Ideal $)$

$S B_{i}=$ Ideal Standard Deciation

$S B_{i}=\frac{1}{6}($ Score Max Ideal - Score Min Ideal $)$

Learning devices are said to be valid for use in trials if the validity score of each learning device has a valid minimum category. Thus, the results of data analysis that do not meet the valid minimum category in this research will be taken into consideration to revise the learning device before being tested. The learning device is said to be practical if the score of each learning device has a practical minimum category, and the percentage of learning achievement reaches $80 \%$. Learning device is said to be effective if $70 \%$ of the number of students meet the minimum completeness criteria [15].

\section{RESULT AND DISCUSSION}

\section{A. Research Results and Discussion}

The development of this learning device uses the 4D development model. The development model consists of four stages: define, design, develop and disseminate. The define stage describes the five phases of activities carried out, which are the initial-final analysis, student analysis, concept analysis, task analysis and specification of learning objectives.

The second stage is the design stage. This stage is to design a learning device prototype. This stage starts after the learning objectives are made. The design stage includes four steps, which are test preparation, media selection, format selection, and initial design. The next step is to develop. This stage consists of expert validation, limited trials and field trials. After instruments and products are made before testing, the instruments and products are validated by experts. Validation results from experts are presented in Table 2 below.

TABLE II.

LEARNING DEVICE VALIDATION SCORE

\begin{tabular}{|c|c|c|c|}
\hline \multirow[t]{2}{*}{ Validator } & \multicolumn{3}{|c|}{ Validated Learning Device Score } \\
\hline & RPP & LKS & TPB \\
\hline 1 & 180 & 70 & 258 \\
\hline 2 & 179 & 69 & 242 \\
\hline Total Score & 359 & 139 & 500 \\
\hline Mean & 179.5 & 69.5 & 250 \\
\hline
\end{tabular}

Analysis of the validation results above for RPP is in the Valid category and is "feasible to use", for LKS is in the Very Valid category and is "feasible to use" while TPB is in the Very Valid category and is "feasible of use with revision". This is supported by the preparation of RPP which refers to the principles and components that exist in the Regulation of Minister of Education and Culture No. 65 of 2013 concerning Process Standards. The preparation of LKS refers to the stages of LKS preparation according to the Ministry of National Education [16]. The preparation of TPB is adjusted to the 
principles put forward by Regulation of Minister of Education and Culture No. 66 of 2013 concerning Assessment Standards.

Furthermore, after being revised based on the input from the validator the learning device it was then used for limited trials. This limited trial was conducted on 35 students of grade VII of Merauke 2 Public Lower Secondary School. Students were asked to read and comment on the learning devices they read and then fill out the student practicality sheets. The learning devices that students read and work on were LKS and TPB. Students were asked to mark each order or sentence that they did not understand and take note as comments to improve the teaching material. Student comments were written on blank paper behind the student practicality sheets.

The result of the limited trial for LKS was Practical with a score of 31.9 and for TPB was Very Practical with a score of 24.8. Comments from students for LKS and TPB were good but there were questions that had double meaning which the made students confused and there was use of language that was not understood by students.

After limited trial, field trial was carried out. The results of the assessment done by the teacher on the products of this research and development are presented in table 3 below.

TABLE III. ANALYSIS RESULTS FROM TEACHERS ON PRODUCTS PRACTICALITY

\begin{tabular}{|l|l|c|l|}
\hline \multicolumn{1}{|c|}{ Product } & \multicolumn{1}{|c|}{ Score } & Interval & Category \\
\hline $\begin{array}{l}\text { Lesson Plan } \\
\text { (RPP) }\end{array}$ & 27 & $22.5<X<27.5$ & Practical \\
\hline $\begin{array}{l}\text { Students Working } \\
\text { Sheets (LKS) }\end{array}$ & 28 & $X>27.5$ & $\begin{array}{l}\text { Very } \\
\text { Practical }\end{array}$ \\
\hline $\begin{array}{l}\text { Learning } \\
\text { Achievement Test } \\
\text { (TPB) }\end{array}$ & 22 & $X>20$ & $\begin{array}{l}\text { Very } \\
\text { Practical }\end{array}$ \\
\hline
\end{tabular}

Besides teachers, students also conducted practicality assessments of products made after they used them. Data from students' assessment of the device practicality were obtained by using student assessment sheets which can be seen in table 4 below.

TABLE IV.

ANALYSIS RESULTS FROM STUDENTS ON PRODUCTS PRACTICALITY

\begin{tabular}{|l|l|c|l|}
\hline \multicolumn{1}{|c|}{ Product } & \multicolumn{1}{c|}{ Score } & \multicolumn{1}{c|}{ Interval } & Category \\
\hline $\begin{array}{l}\text { Students Working } \\
\text { Sheets (LKS) }\end{array}$ & 30.70 & $26.67<\bar{x} \leq 32$ & Practical \\
\hline $\begin{array}{l}\text { Learning } \\
\text { Achievement Test } \\
(\mathrm{TPB})\end{array}$ & 23.49 & $20<\bar{x} \leq 24$ & Practical \\
\hline
\end{tabular}

Based on the results of the practical analysis for LKS and TPB from Table 4, it shows that every aspect assessed is considered to be in the Practical category so that overall it can be said that the developed learning devices reach the practical category.
Analysis of the data obtained from the observations of learning implementation at each meeting is shown in Table 5 below.

TABLE V. ANALYSIS OF OBSERVATION OF LEARNING IMPLEMENTATION

\begin{tabular}{|l|c|c|c|c|c|c|c|c|}
\hline \multirow{2}{*}{ Students } & \multicolumn{7}{|c|}{ Score at Meeting- } \\
\cline { 2 - 10 } & $\mathbf{1}$ & $\mathbf{2}$ & $\mathbf{3}$ & $\mathbf{4}$ & $\mathbf{5}$ & $\mathbf{6}$ & $\mathbf{7}$ & $\mathbf{8}$ \\
\hline Grade VII A & 18 & 19 & 18 & 20 & 20 & 18 & 20 & 19 \\
\hline Grade VIIB & 20 & 18 & 18 & 18 & 19 & 20 & 19 & 20 \\
\hline Total Score & 38 & 37 & 36 & 38 & 39 & 38 & 39 & 39 \\
\hline $\begin{array}{l}\text { Percentage } \\
(\%)\end{array}$ & 86.4 & 84.1 & $\begin{array}{l}81 . \\
8\end{array}$ & $\begin{array}{l}86 . \\
4\end{array}$ & $\begin{array}{l}88 . \\
6\end{array}$ & $\begin{array}{l}86 . \\
4\end{array}$ & $\begin{array}{l}88 . \\
6\end{array}$ & $\begin{array}{l}88 . \\
6\end{array}$ \\
\hline
\end{tabular}

Based on data analysis in Table 11, it can be seen that the percentage of the process of learning implementation at each meeting reaches at least $80 \%$. This shows that the learning device with scientific approach oriented to problem solving ability can be carried out well. Overall it can be concluded that the learning device achieves practical criteria.

Besides being valid and practical, field trials also aim to measure the effectiveness of learning devices. In this research the learning device is said to be effective if it meets the criteria of when the percentage of students achieve Minimum Completeness Criteria of at least $70 \%$. The effectiveness of learning devices developed (RPP and LKS) was reviewed in terms of aspects of student learning achievement. Aspects of student learning achievement were measured based on TPB results data. Then the percentage of students' individual and classical learning completeness will be seen.

Data on the results of student learning achievement tests are presented in table 6 below.

TABLE VI. PERCENTAGE OF COMPLETENESS OF LEARNING

\begin{tabular}{|l|c|c|c|c|}
\hline Students & $\begin{array}{c}\text { Mean } \\
\text { Score }\end{array}$ & $\begin{array}{c}\text { Number of } \\
\text { Students } \\
\text { Achieving } \\
\text { KKM }\end{array}$ & $\begin{array}{c}\text { Total } \\
\text { Studen } \\
\text { ts }\end{array}$ & $\begin{array}{c}\text { Completen } \\
\text { ess } \\
\text { Percentage }\end{array}$ \\
\hline $\begin{array}{l}\text { Grade VII } \\
\text { A }\end{array}$ & 74.60 & 17 & 21 & $80.95 \%$ \\
\hline $\begin{array}{l}\text { Grade VII } \\
\text { B }\end{array}$ & 73.18 & 16 & 22 & $72.73 \%$ \\
\hline
\end{tabular}

The results of the analysis of the completeness of learning in the table above show that the level of completeness for grade VII A and Class VII B of Merauke 8 Public Lower Secondary School is $80.95 \%$ and $72.73 \%$ respectively. This shows that students have achieved the KKM (Minimum Completeness Criteria) set by the school which is 69 . So it can be concluded that the learning devices developed have achieved effective criteria. In this case, [17] stated that the higher the student's involvement, for example in the problem solving process, the more meaningful the mathematics learning will be for students. This certainly has a positive impact on mathematics learning. 


\section{CONCLUSION}

The results and discussion of the research show that the quadrilateral and triangular learning devices in lower secondary school with a scientific approach oriented to problem solving abilities conclude that RPP, LKS and TPB have met the Valid, Practical and Effective criteria. The effectiveness of the product can be seen from the percentage of learning completeness that has reached the KKM (minimum completeness criteria) which are $80.95 \%$ and $72.73 \%$ respectively.

\section{ACKNOWLEDGMENT}

We thank Universitas Musamus for facilities and supports. This project was supported by DRPM Ristekdikti and the publication was supported by Universitas Musamus.

\section{REFERENCE}

[1] Nizam and Puspendik, "Ringkasan Hasil-hasil Asesmen."

[2] S. Ar, Turmudi, D. Suryadi, and E. Al, Strategi Pembelajaran Matematika Kontemporer. Bandung: JICA-UPI, 2003.

[3] NCTM, Principles and Standards for Scholl Mathematics. Reston, VA: NCTM Inc, 2000.

[4] S. Pimta, S. Tayruakham, and P. Nuangchale, "Factors Influencing Mathematic Problem-Solving Ability of Sixth Grade Students," J. Soc. Sci., vol. 5, no. 4, pp. 381-385, 2009.
[5] I. Marlissa and D. Widjajanti, "Pengaruh Strategi React Ditinjau Dari Gaya Kognitif Terhadap Kemampuan Pemecahan masalah, Prestasi Belajar dan Apresiasi Siswa Terhadap Matematika," Ris. Pendidik. Mat., vol. 2, no. November, pp. 162-174, 2015.

[6] J.W. Santrock, Educational Psycology. Newyork: McGraw-Hill Companies, 2011.

[7] J. Bransford and B. S. Stein, The Ideal Problem Solver: A Guide for Improving Thinking, Learning, and Creativity, Second. Newyork: W.H Freeman, 1993.

[8] Y. Lahinda and J. Jailani, "Analisis proses pemecahan masalah matematika siswa sekolah menengah pertama," J. Ris. Pendidik. Mat., vol. 2, no. 1, p. 148, 2015.

[9] Masrurotullaily, Hobri, and Suharto, "Analisis Kemampuan Pemecahan Masalah Matematika Keuangan Berdasarkan Model Polya Siswa Smk Negeri 6 Jember," Kadikma, vol. 4, no. 2, pp. 129-138, 2013.

[10] D.P.S.M. Atas, Panduan Pengembangan Bahan Ajar. 2008.

[11] BPSDMPK and PMP, "Materi Pelatihan Implementasi Kurikulum 2013 Tahun 2014," p. 197, 2014.

[12] I. Marlissa and J. R. Untayana, "Implementation of 2013-Curriculum with a Scientific Approach at SMPN 2 Merauke,” vol. 174, no. Ice 2017, pp. 463-465, 2018.

[13] A. Mahmudi, "Pendekatan Saintifik dalam Pembelajaran Matematika," Semin. Nas. Mat. Dan Pendidik. Mat. Uny, no. 1, pp. 561-566, 2015.

[14] M. F. Atsnan, "Pengembangan Perangkat Pembelajaran Vektor dengan Pendekatan Creative Problem Solving Kelas XI SMK Teknokestan," Ris. Pendidik. Mat., vol. 2, no. November, pp. 162-174, 2015.

[15] S. Azwar, Tes Prestasi Fungsi Pengembangan Pengukuran Prestasi Belajar. Yogyakarta: Pustaka Belajar, 2010.

[16] Depdiknas, Depdiknas Peraturan Menteri Pendidikan nasional RI No 2 Tahun 2008 Tentang Buku. Jakarta, Indonesia.

[17] Warsono and Hariyanto, Pembelajaran Aktif. Bandung: PT Remaja Rosdakarya, 2013. 